\title{
Caracterização morfológica e imuno-histoquímica de lesões em casos de aborto bovino bacteriano e viral no sul de Minas Gerais ${ }^{1}$
}

\author{
Débora Ribeiro Orlando ${ }^{2}$, Rafael Carneiro Costa ${ }^{2}$, Rafael Vitor S. Abreu², Camila \\ Costa Abreu², Karen Yumi Ribeiro Nakagaki ${ }^{2}$, Angelica T. Barth Wouters ${ }^{2}$, Djeison \\ Lutier Raymundo ${ }^{2}$ e Mary Suzan Varaschin ${ }^{2 *}$
}

\begin{abstract}
Orlando D.R., Costa R.C., Abreu R.V.S., Abreu C.C., Nakagaki K.Y.R., Wouters A.T.B., Raymundo D.L. \& Varaschin M.S. 2014. [Morphological and immunohistochemical characterization of the lesions in cases of bacterial and viral bovine abortion in southern Minas Gerais, Brazil.] Caracterização morfológica e imuno-histoquímica de lesões em casos de aborto bovino bacteriano e viral no sul de Minas Gerais. Pesquisa Veterinária Brasileira 34(10):974-980. Setor de Patologia Veterinária, Universidade Federal de Lavras, Cx. Postal 3037, Lavras, MG 37200-000, Brazil. E-mail: msvaraschin@dmv.ufla.br

The paper evaluates the participation of bacterial and viral agents in bovine abortions in farms of southern Minas Gerais state, Brazil. Histopathological and immunohistochemical analysis was performed in aborted fetuses of cattle received by the Setor de Patologia Veterinária, Universidade Federal de Lavras, from 1999 to 2013. From 60 fetuses studied, $30(50 \%)$ had microscopic lesions. From these, eight had lesions consistent with bacterial agents and three had lesions suggestive of viral agents. In the bacterial abortions, one fetus presented lesions compatible with leptospirosis, characterized by jaundice, cholestasis, lymphoplasmacytic intersticial nephritis, and tubular nephrosis. Seven fetuses had purulent pneumonia or bronchopneumonia and one of them had also fibrinous pleuritis and peritonitis; two of them presented positive immunostaining for Brucella abortus. One of the three fetuses with lesions of viral infection revealed positive imunostaining for bovine herpesvirus. The results showed that abortions of bacterial and viral origin occur in the Region of this study and prophylactic measures should be adopted on the farms. This study also demonstrates that immunohistochemistry associated with histopathology is a useful and viable tool for the diagnosis, especially when microbiological and/or serological tests are not available.
\end{abstract}

INDEX TERMS: Brucellosis, leptospirosis, abortion, fetal losses, livestock.

RESUMO.- 0 presente estudo avaliou a participação de agentes bacterianos e virais em abortos em bovinos de propriedades rurais do sul de Minas Gerais. Foi realizada análise histopatológica e imuno-histoquímica dos casos de aborto recebidos pelo Setor de Patologia Veterinária da Universidade Federal de Lavras no período de 1999 a 2013. De 60 fetos analisados, em 30 (50\%) foram observadas lesões microscópicas. Destes, oito apresentavam lesões compatíveis com infecção por agentes bacterianos e

\footnotetext{
${ }^{1}$ Recebido em 5 de maio de 2014.

Aceito para publicação em 29 de setembro de 2014.

${ }^{2}$ Setor de Patologia Veterinária, Universidade Federal de Lavras (UFLA), Cx. Postal 3037, Lavras, MG 37200-000, Brasil. *Autor para correspondência: msvaraschin@dmv.ufla.br
}

três apresentaram lesões sugestivas de agentes virais. Dos abortos bacterianos, um feto tinha lesões compatíveis com leptospirose, caracterizadas por icterícia e colestase, nefrite intersticial linfoplasmocítica e nefrose tubular. Sete fetos apresentaram pneumonia ou broncopneumonia purulenta; num deles havia também pleurite e peritonite fibrinosas; e em dois desses fetos houve imunomarcação para Brucella abortus. Dos três fetos com lesões sugestivas de aborto viral ocorreu imunomarcação anti-Herpesvírus bovino em um. Os resultados demonstram a ocorrência de abortos de origem bacteriana e viral na Região do estudo e que medidas profiláticas devem ser adotadas nas propriedades. 0 trabalho demonstra também que a imuno-histoquímica (IHQ); associada à histopatologia; é uma ferramenta útil 
e viável para o diagnóstico, especialmente quando provas microbiológicas e/ou sorológicas não estão disponíveis.

TERMOS DE INDEXAÇÃO: Brucelose, leptospirose, abortos, perdas fetais, animais de produção.

\section{INTRODUÇÃO}

A pecuária bovina desempenha importante papel na economia do Brasil e as doenças que cursam com perdas reprodutivas sempre resultam em prejuízos para o produtor. Nos rebanhos bovinos brasileiros, a diversidade de condições de manejo, a falta de suporte laboratorial e o envio de fetos em autólise para necropsia dificultam o diagnóstico da etiologia do aborto, de maneira que faltam ainda muitas informações sobre as causas de aborto em bovinos no Brasil (Antoniassi et al. 2013).

Entre as diversas etiologias do aborto, destacam-se as de origem infecciosa, com abortos causados por protozoários, bactérias, vírus e fungos. Abortos por protozoários em bovinos são associados principalmente à infecção por Neospora caninum (Corbellini et al. 2002, Orlando et al. 2013), mas podem ser causados também por Tritrichomonas foetus (Alves et al. 2011). Abortos bacterianos são associados a Brucela abortus, Leptospira sp., Listeria monocytogenes e Campylobacter sp. (Varaschin \& Wouters 2006, Alves et al. 2011); já os de origem viral são relacionados ao Vírus da Diarreia Viral Bovina (VDVB) e ao Herpesvírus Bovino tipo I (HVB-1) (Varaschin \& Wouters 2006, Antoniassi et al. 2013).

O objetivo do presente trabalho foi descrever as principais lesões observadas nos abortos bovinos causados por agentes bacterianos e pelo Herpesvírus bovino, bem como os achados no uso da técnica de IHQ para a identificação de agentes causadores de aborto.

\section{MATERIAL E MÉTODOS}

\section{Origem e característica das amostras}

Foram avaliados os casos de aborto bovino recebidos pelo Setor de Patologia Veterinária da Universidade Federal de Lavras (SPV-UFLA), Minas Gerais, Brasil, no período de 1999 a 2013.

Foi realizada anamnese com proprietários e/ou veterinários para a obtenção do histórico dos fetos recebidos no período de 2011 a 2013, com coleta de informações sobre manejo e profilaxia. A idade fetal foi determinada pelos registros de cobertura das mães associados à mensuração do feto na necropsia, conforme recomendada por Barr et al. (1990).

$\mathrm{Na}$ necropsia foram colhidas amostras de sistema nervoso central (SNC), músculos esqueléticos (cleido-occipital, semitendíneo, semimembranáceo, infraespinhal e diafragma), língua, coração, esôfago, pulmão, fígado, rim, baço, linfonodos mesentéricos, intestinos, timo, válvula ileocecal, ovário/testículo, útero, pele, rúmen, retículo, omaso, abomaso e gânglio trigeminal, em formalina a 10\% tamponada e processadas rotineiramente para histopatologia. Cortes de $5 \mu \mathrm{m}$ de espessura foram corados por hematoxilina e eosina (HE) e avaliados à microscopia ótica.

\section{Teste de microaglutinação (MAT), histoquímica e imuno-his- toquímica}

Amostras de soro sanguíneo das vacas que abortaram foram encaminhadas ao Laboratório de Leptospirose da Universidade Federal de Minas Gerais (UFMG) para a realização do MAT para vários sorovares de Leptospira sp. Foram considerados positivos os soros diluídos a partir de 1:100 para sorovar Hardjo com, no mínimo, 50\% de leptospiras aglutinadas no campo microscópico, conforme descrito por Chiareli et al. (2012). Amostras de fígado e rim do feto suspeito de aborto por Leptospira sp. foram submetidas à técnica histoquímica de impregnação pela prata (Wartin-Starry).

Os tecidos dos fetos que apresentaram lesões compatíveis com aborto bacteriano ou viral foram submetidos à técnica de IHQ para pesquisa e identificação dos antígenos específícos. Dados sobre recuperação antigênica, anticorpos e diluição usados são detalhados no Quadro 1.

Como controle positivo para Herpesvírus bovino foram utilizadas amostras de bovino com encefalite por Herpesvírus bovino tipo 5; para VDVB amostras de tecido linfoide e pele de animais adultos positivos na IHQ; e para brucelose foram utilizados fetos positivos na IHQ.

\section{RESULTADOS}

De 60 fetos estudados 30 (50\%) apresentaram lesões microscópicas. Destes, três fetos (fetos 3, 4 e 6) apresentaram lesões compatíveis com aborto por vírus; e oito (fetos 1,2 , $5,7,8,9,10$ e 11) apresentaram lesões compatíveis com aborto bacteriano (Quadro 2).

\section{Histórico clínico, teste sorológico e lesões macroscópicas}

Em uma das propriedades com diagnóstico anterior de aborto bovino de origem viral, os casos cessaram após vacinação das vacas contra HVB/VDVB. No entanto, a vacinação havia sido interrompida por mais de dois anos e novos casos de aborto ocorreram. 0 feto proveniente dessa

Quadro 1. Recuperação antigênica, especificações, diluições e origem dos anticorpos primários utilizados na técnica de imuno-histoquímica em casos de aborto bovino bacteriano e viral

\begin{tabular}{|c|c|c|c|c|}
\hline $\begin{array}{l}\text { Anticorpo } \\
\text { primário }\end{array}$ & $\begin{array}{c}\text { Especificações } \\
\text { do anticorpo }\end{array}$ & $\begin{array}{c}\text { Recuperação } \\
\text { antigênica }\end{array}$ & $\begin{array}{l}\text { Diluição do } \\
\text { anticorpo }\end{array}$ & $\begin{array}{l}\text { Referência } \\
\text { comercial }\end{array}$ \\
\hline $\begin{array}{l}\text { Herpesvírus } \\
\text { bovino tipo } 5^{\text {a }}\end{array}$ & $\begin{array}{c}\text { Monoclonal } \\
\text { Clones 2F9.E9 } \\
\text { e 4E4 }\end{array}$ & $\begin{array}{c}\text { Proteinase } \mathrm{K} \\
15 \text { min em temperatura } \\
\text { ambiente }\end{array}$ & $1: 500$ & UFSM \\
\hline $\begin{array}{l}\text { Brucella } \\
\text { abortus }\end{array}$ & Policlonal & $\begin{array}{c}\text { Tripsina } 0,1 \%(\mathrm{pH} 7,8) \\
10 \text { min a } 37^{\circ} \mathrm{C} \text { e calor } 2 \text { min } \\
\text { em tampão citrato }(\mathrm{pH} 6,0)\end{array}$ & $1: 50$ & UFMG \\
\hline $\mathrm{BVDV}^{\mathrm{b}}$ & $\begin{array}{l}\text { Monoclonal } \\
\text { D89 }\end{array}$ & $\begin{array}{c}\text { Tripsina } 0,1 \%(\mathrm{pH} 7,8) \\
10 \text { min a } 37^{\circ} \mathrm{C} \text { e calor } 2 \text { min } \\
\text { em tampão citrato }(\mathrm{pH} 6,0)\end{array}$ & $1: 50$ & $\begin{array}{l}\text { VRMD, Inc., } \\
\text { Pullman, USA }\end{array}$ \\
\hline
\end{tabular}

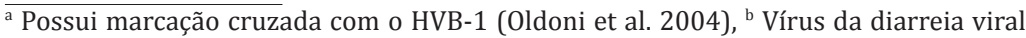
bovina. 
Quadro 2. Relação dos fetos com diagnóstico de aborto por agentes bacterianos e virais analisados no Setor de Patologia Veterinária da UFLA no mperiodo de 1999 a 2013

\begin{tabular}{|c|c|c|c|}
\hline Feto & $\begin{array}{l}\text { Idade gesta- } \\
\text { cional (meses) }\end{array}$ & $\begin{array}{l}\text { Achados morfológicos } \\
\text { mais importantes }\end{array}$ & $\begin{array}{l}\text { Diagnóstico } \\
\text { definitivo }\end{array}$ \\
\hline 1 & 8 & $\begin{array}{l}\text { Broncopneumonia } \\
\text { necrosante multifocal }\end{array}$ & Brucelose \\
\hline 2 & 8 & $\begin{array}{l}\text { Pneumonia purulenta com } \\
\text { cocos intralesionais }\end{array}$ & $\begin{array}{c}\text { Aborto } \\
\text { bacteriano }\end{array}$ \\
\hline 3 & 5 & $\begin{array}{l}\text { Braquignatia e necrose } \\
\text { linfoide moderada }\end{array}$ & $\begin{array}{l}\text { Aborto } \\
\text { viral }^{\mathrm{a}}\end{array}$ \\
\hline 4 & 8 & $\begin{array}{l}\text { Braquignatia e necrose } \\
\text { linfoide moderada }\end{array}$ & $\begin{array}{l}\text { Aborto } \\
\text { viral }^{\text {a }}\end{array}$ \\
\hline 5 & 7 & $\begin{array}{l}\text { Broncopneumonia } \\
\text { purulenta com coco- } \\
\text { bacilos intralesionais }\end{array}$ & $\begin{array}{c}\text { Aborto } \\
\text { bacteriano }\end{array}$ \\
\hline 6 & 8 & $\begin{array}{l}\text { Necrose linfoide } \\
\text { moderada }\end{array}$ & $\begin{array}{l}\text { Aborto por Herpes- } \\
\text { vírus bovino }\end{array}$ \\
\hline 7 & 7 & $\begin{array}{l}\text { Broncopneumonia } \\
\text { purulenta }\end{array}$ & $\begin{array}{c}\text { Aborto } \\
\text { bacteriano }\end{array}$ \\
\hline 8 & 7 & $\begin{array}{l}\text { Pleurite e peritonite fibrinosas } \\
\text { e pneumonia purulenta }\end{array}$ & Brucelose \\
\hline 9 & 8 & $\begin{array}{l}\text { Nefrite intersticial linfoplas- } \\
\text { mocítica, nefrose tubular e } \\
\text { dissociação de hepatócitos }\end{array}$ & Leptospirose \\
\hline 10 & 6 & $\begin{array}{l}\text { Pneumonia purulenta } \\
\text { difusa acentuada }\end{array}$ & $\begin{array}{c}\text { Aborto } \\
\text { bacteriano }\end{array}$ \\
\hline 11 & 8 & $\begin{array}{l}\text { Broncopneumonia } \\
\text { purulenta }\end{array}$ & $\begin{array}{c}\text { Aborto } \\
\text { bacteriano }\end{array}$ \\
\hline
\end{tabular}

a Diagnóstico definido com base nos achados morfológicos macro e microscópicos.

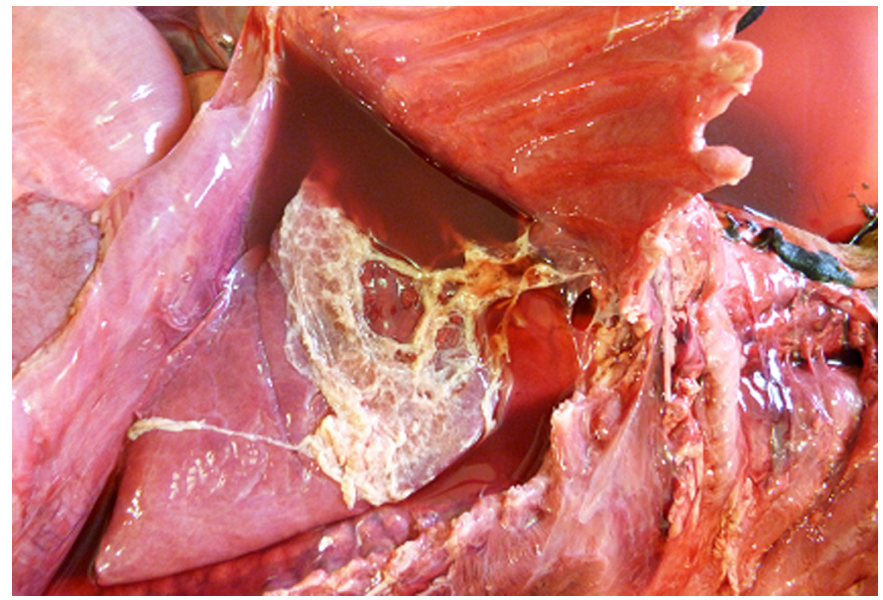

Fig.1. Aborto bovino por agentes bacterianos (Brucelose, Feto 8). Cavidade torácica com líquido avermelhado e espessa camada de fibrina envolvendo os pulmões.

propriedade (feto 6) não apresentou lesões macroscópicas. Nas outras duas propriedades os animais não eram vacinados contra HVB/VDVB; os dois fetos (fetos 3 e 4) oriundos delas apresentaram braquignatia. Alguns fetos foram encaminhados para exame sem histórico clínico.

Alterações macroscópicas foram observadas em três dos oito fetos diagnosticados como aborto bacteriano. No feto 5 observou-se líquido translúcido nas cavidades abdominal (300 mL) e torácica $(600 \mathrm{~mL})$. No feto 8 havia grande quantidade de líquido avermelhado nas cavidades abdominal e torácica e a pleura pulmonar (Fig.1), o omento e alças intestinais (Fig.2) encontravam-se cobertas por espessa

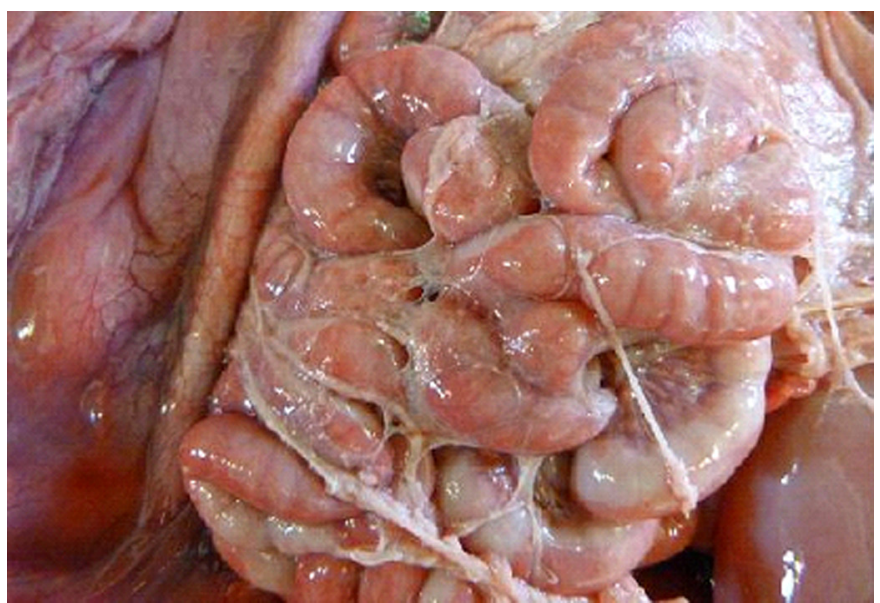

Fig.2. Aborto bovino por agentes bacteriano (Brucelose, Feto 8). Cavidade abdominal com omento e alças intestinais envoltos por espessa camada de fibrina.

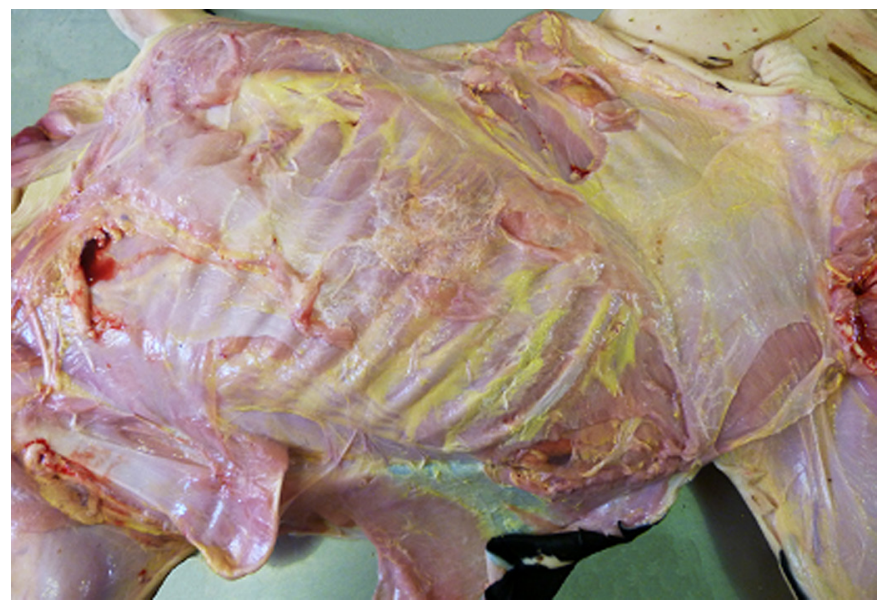

Fig.3. Aborto bovino por agentes bacterianos (Leptospirose, Feto 9). Tecido Subcutâneo evidenciando icterícia moderada.

camada de fibrina, com aderência entre pleura visceral e parietal em alguns pontos.

Em uma propriedade (feto 9) as vacas haviam sido vacinadas contra leptospira em outubro de 2012 (vacina comercial), no entanto, casos de aborto começaram a ocorrer em abril de 2013, após entrada de chorume no reservatório da água destinada ao consumo dos bovinos, por um erro no manejo do sistema hidráulico. Na necropsia do feto foram observados icterícia moderada (Fig.3), fígado aumentado de volume e vermelho-amarelado e no timo havia hemorragias multifocais. As vacas que abortaram apresentaram reação anti-Leptospira sorovar Hardjo positiva no MAT, com $75 \%$ de leptospiras aglutinadas para as sorovariedades Hardjo genótipo Hardjobovis e Hardjoprajitino (amostra Bolívia isolada em rebanho mineiro, conforme Chiareli et al. 2012) e Hardjo O.M.S.(amostra de referência).

\section{Lesões microscópicas e marcação IHQ em fetos suspei- tos de aborto por vírus}

Em todos os fetos com suspeita de aborto por vírus observou-se necrose linfoide moderada em acúmulos linfoides de timo, válvula ileocecal, linfonodos e baço. 
No feto 6, proveniente de propriedade com histórico de aborto viral, foi observada imunomarcação com o anticorpo monoclonal anti-Herpesvírus bovino tipo 5, cepa 4E4. A marcação ocorreu no citoplasma de células do baço (Fig.4), de linfonodos mesentéricos, em células de Kupffer, macrófagos pulmonares e no citoplasma de neurônios do tálamo. No colículo caudal ocorreu imunomarcação em células endoteliais de vasos sanguíneos (Fig.5). Nos outros dois fetos
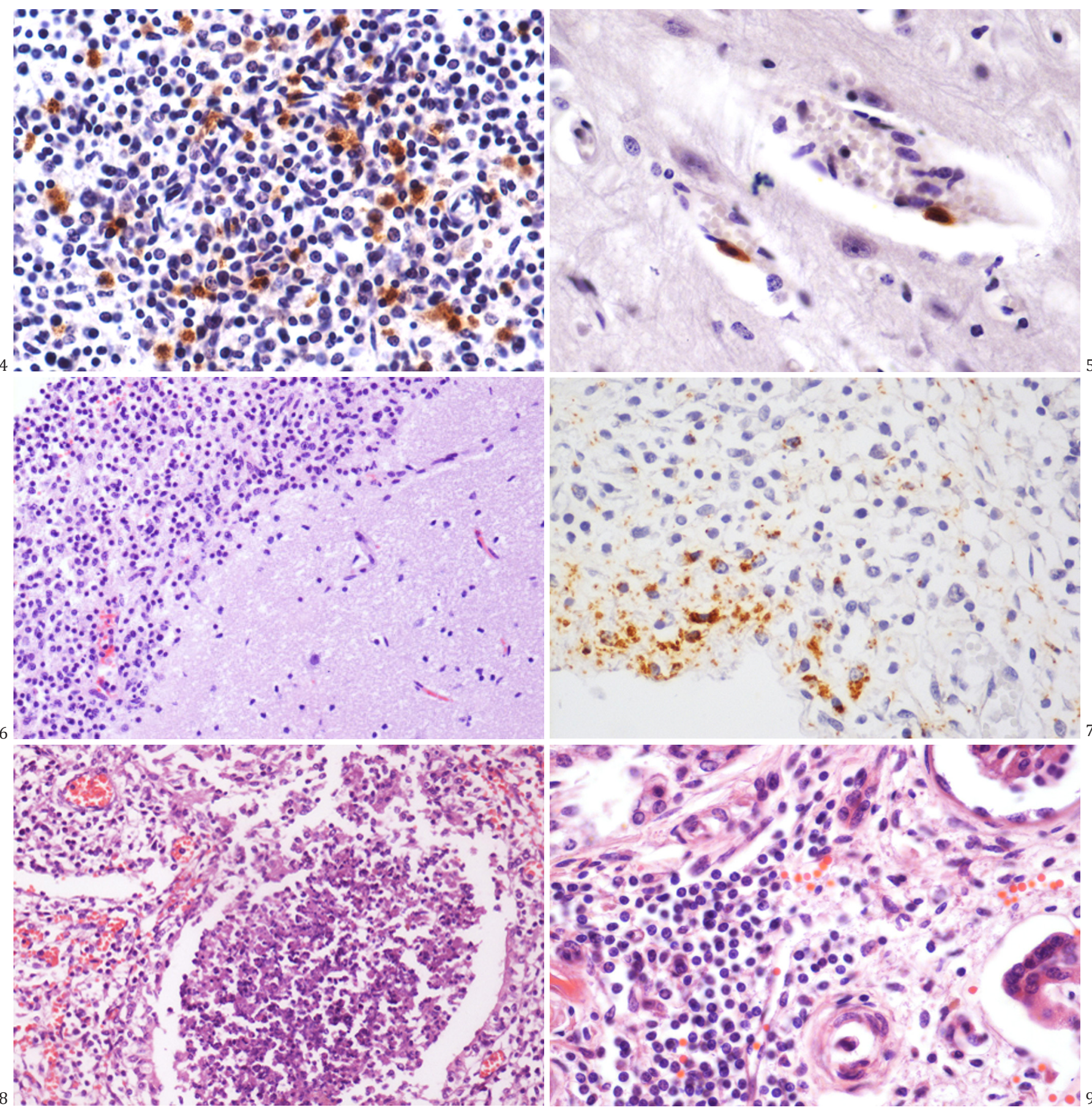

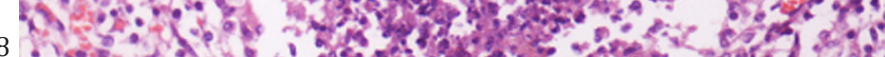

Fig.4. Aborto bovino por agentes virais (Herpesvírus bovino tipo

1, Feto 6). Imunomarcação no citoplasma de células linfóides do baço. Método da streptavidina biotina, cromógeno DAB, obj.40x.

Fig.6. Aborto bovino por agentes bacterianos (Brucelose, Feto 8). Meningite mononuclear acentuada. HE, obj.40x.

Fig.8. Aborto bovino por agentes bacterianos (Brucelose, Feto 1). Células necróticas no interior de brônquio e alvéolos. HE, obj.40x.

Fig.5. Aborto bovino por agentes virais (Herpesvírus bovino tipo 1, Feto 6). Imunomarcação no citoplasma de células endoteliais do colículo caudal. Método da streptavidina biotina, cromógeno DAB, obj.40x.

Fig.7. Aborto bovino por agentes bacterianos (Brucelose, Feto 8). Imunomarcação anti-Brucella abortus no citoplasma de células inflamatórias na pleura. Método da streptavidina biotina, cromógeno DAB, obj.40x.

Fig.9. Aborto bovino por agentes bacterianos (Leptospirose, Feto 9). Nefrite intersticial mononuclear. HE, obj.40x. 


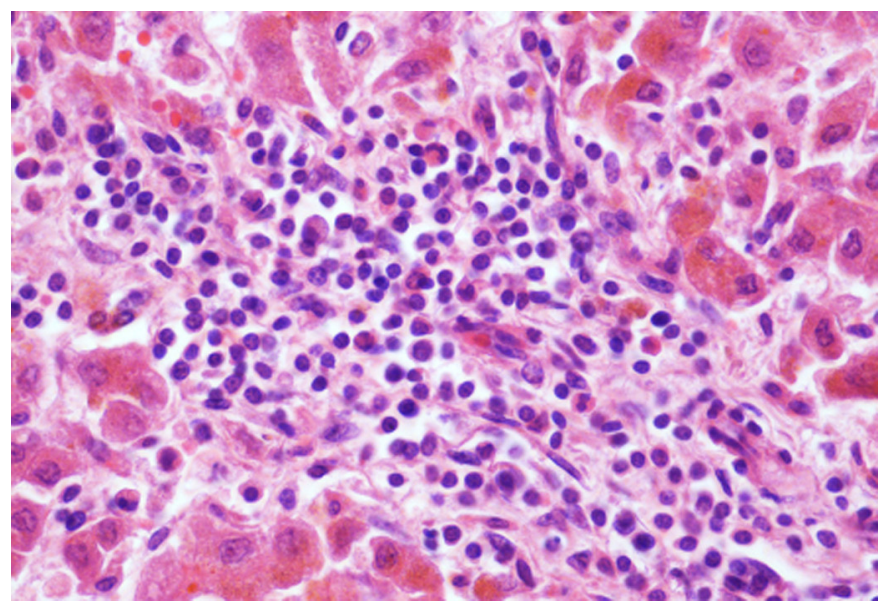

Fig.10. Aborto bovino por agentes bacterianos (Leptospirose, Feto 9). Intenso infiltrado mononuclear e colestase intra-hepática. HE. obj.40x.

(fetos 3 e 4) com braquignatia e nos controles negativos não ocorreu marcação na IHQ para VDVB e para Herpesvírus.

\section{Lesões microscópicas e marcação imuno-histoquímica} em fetos suspeitos de aborto bacteriano

No feto 8 foi observada pleurite fibrinosa acentuada caracterizada por infiltrado acentuado de células mononucleares e fibrina e, na luz alveolar, havia pequena quantidade de neutrófilos. Havia também meningite, com infiltrado composto predominantemente por linfócitos e macrófagos (Fig.6) e raros neutrófilos nas regiões de córtex cerebral, tálamo, cerebelo e segmento cervical da medula espinhal. Na serosa de fígado, abomaso, intestinos delgado e grosso e gordura mesentérica havia infiltrado inflamatório mononuclear difuso acentuado que, no abomaso e nos intestinos, se estendia, em alguns focos, à submucosa. A marcação IHQ anti-Brucella abortus revelou bactérias na forma de cocobacilos no citoplasma de células inflamatórias, principalmente macrófagos, na pleura visceral (Fig.7), em meninges, na serosa intestinal e em linfonodos mesentéricos.

O feto 1 apresentou broncopneumonia necrosante multifocal, caracterizada por discreto a moderado infiltrado inflamatório constituído por macrófagos e neutrófilos no interstício pulmonar, associado a pequena quantidade de fibrina e necrose de células inflamatórias no interior de alvéolos e brônquios (Fig.8). Houve marcação anti-Brucella abortus em restos celulares de focos de necrose pulmonar e no citoplasma de macrófagos.

No feto 10 observou-se pneumonia purulenta difusa acentuada, caracterizada por intenso infiltrado neutrofílico, moderado de macrófagos e raros filetes de fibrina na luz de alvéolos. Esse infiltrado era observado nos septos lobulares associado a focos de hemorragia. Nos seios medulares dos linfonodos havia macrófagos. Este caso foi negativo para Brucella sp. na IHQ, por isso classificado somente como aborto bacteriano.

Nos fetos 2, 7 e 11, observou-se infiltrado de neutrófilos e células mononucleares associado a filetes de fibrina na luz de brônquios e em alvéolos, sendo que, no feto 2 , havia também bactérias na forma de cocos nos pulmões.

No pulmão do feto 5 havia grande quantidade de neutrófilos, alguns macrófagos e moderada quantidade de fibrina em brônquios, bronquíolos e alvéolos, associadas a colônias bacterianas cocobacilares. Infiltrado de neutrófilos e macrófagos também foi observado no timo e em sinusoides hepáticos.

No feto 9 foram visualizados, microscopicamente, nefrite intersticial linfoplasmocítica (Fig.9) multifocal moderada, vacuolização do citoplasma das células do epitélio tubular, com focos de necrose em túbulos contorcidos proximais e pigmento marrom no citoplasma do epitélio tubular. No fígado havia dissociação de hepatócitos e infiltrado periportal de linfócitos, plasmócitos e macrófagos, além de acentuada colestase intra-hepática (Fig.10). Foram também observados hemorragias multifocais em timo, pulmão e córtex cerebral, discreto espessamento de septos alveolares e neutrófilos em capilares alveolares no pulmão. A impregnação pela prata resultou negativa.

\section{DISCUSSÃO}

Dos 60 fetos avaliados são descritos 11 casos neste trabalho com lesões de infecção bacteriana ou viral. Dezenove fetos, que apresentaram lesões compatíveis com infecção por $N$. caninum e confirmação diagnóstica por IHQ e PCR em 14 deles, foram descritos por Orlando et al. (2013). Nos outros 30 fetos, sem lesões microscópicas, não podem ser descartadas causas não infecciosas de aborto, evidenciadas no histórico desses casos; em duas propriedades houve relato de medicação com corticoide nas vacas gestantes e, em várias propriedades, havia histórico de escassez alimentar.

Para o diagnóstico foram consideradas as lesões compatíveis com os agentes pesquisados, associadas principalmente à marcação imuno-histoquímica. 0 diagnóstico etiológico foi obtido em $45 \%$ dos fetos bovinos com lesões sugestivas de aborto bacteriano ou viral. Esses dados demonstram a dificuldade de se chegar ao diagnóstico etiológico nos casos de aborto. Deve ser levado em conta que, para dois dos casos de aborto bacteriano e um viral, havia apenas material em parafina disponível para o diagnóstico. Kirkbride (1992) apresenta definição do diagnóstico etiológico em somente 30 a $40 \%$ dos fetos bovinos abortados. Resultados semelhantes são também descritos por Cortez et al. (2006), que pesquisaram ácidos nucleicos de VDVB, HVB, Brucella sp. e Leptospira sp. pela PCR e, em 77,4\% de 114 fetos encaminhados para diagnóstico laboratorial, não foi possível detectar nenhum dos agentes pesquisados. Além disso, muitos fetos são encaminhados ao laboratório autolisados ou congelados, dificultando a identificação do agente etiológico.

A principal alteração histológica do feto com diagnóstico de aborto por Herpesvírus foi necrose de células linfoides em timo, válvula ileocecal, linfonodos e baço. Outros autores descrevem necrose linfoide com depleção secundária (Enright et al. 1984, Rodger et al. 2007) e necrose e infiltrado inflamatório mononuclear periportal no fígado, além de focos de necrose pulmonar e hemorragias na região medular dos rins (Rodger et al. 2007) em casos de aborto por Herpesvírus bovino tipo 1 . 
Oldoni et al. (2004) observaram, na produção de anticorpos monoclonais a partir de isolados de Herpesvírus bovino tipo 5, provenientes de amostras de vacas com sinais neurológicos no Rio Grande do Sul, que nove desses anticorpos tiveram reação cruzada com 10 isolados de Herpesvírus bovino tipo 1 . No presente estudo foram usados dois tipos desses anticorpos, mas somente um (anticorpo monoclonal 4E4) foi efetivo na imunomarcação, definindo o diagnóstico de aborto por Herpesvírus bovino. A marcação ocorreu em vários tecidos, sendo mais significativa no baço. No presente estudo observou-se marcação no citoplasma de células linfoides intactas de áreas com e sem necrose, assim como em focos no citoplasma de neurônios e em algumas células endoteliais. No controle positivo ocorreu marcação em todo o neurônio, incluindo seus prolongamentos. Crook et al. (2012), no estudo em abortos por Herpesvírus tipo 1 também obtiveram imunomarcação em vasos e difusa no citoplasma de neurônios. Essas diferenças podem estar relacionadas ao uso de diferentes cepas do vírus. Rodger et al. (2007) descrevem marcação em hepatócitos e em células de baço e linfonodos, nestes tanto na região medular como na cortical. Essa marcação nos tecidos linfoides foi semelhante ao encontrado neste estudo. Os outros dois fetos, com achado histológico de necrose de células linfoides; na necropsia apresentaram braquignatia, alterações associadas à infecção por VDVB (Flores \& Schuch 2007).

O diagnóstico de aborto por B. abortus foi baseado em lesões macro e microscópicas associadas à marcação IHQ. Os achados são semelhantes aos descritos na literatura (Carvalho Neta 2010, Antoniassi et al. 2013). 0 achado de meningite mononuclear com imunomarcação de bactérias, principalmente no citoplasma de macrófagos, é também descrito por Hong et al. (1991). Antoniassi et al. (2013) observaram $1,43 \%$ dos abortos em bovinos causados por $B$. abortus; $1,22 \%$ por Sthaphylococcus aureus e $0,6 \%$ por Leptospira sp. Os outros cinco casos com lesões pulmonares compatíveis com pneumonia bacteriana tiveram resultado negativo na IHQ anti-Brucella. Na necropsia dos fetos abortados recebidos no período de 2011 a 2013 foram também colhidas amostras para exames microbiológicos, no entanto, das amostras de dois dos fetos (fetos 7 e 10), encaminhadas para cultura bacteriológica cresceram somente bactérias oportunistas, provavelmente devido à demora no encaminhamento dos fetos para necropsia e, no período do estudo, houve também dificuldade quanto a apoio laboratorial na área de microbiologia veterinária.

O diagnóstico de aborto por Leptospira sp. baseou-se nos achados macro e microscópicos de nefrite intersticial linfoplasmocítica com tubulonecrose multifocal discreta, associados às lesões hepáticas de dissociação dos hepatócitos e colestase. Antoniassi et al. (2013) descrevem lesões semelhantes nos casos de aborto por Leptospira sp. Não houve impregnação de Leptospira na coloração especial. Segundo Szeredi \& Haake (2006), outras formas da leptospira também não são detectadas pelas colorações de prata. Além disso, a extensa impregnação da reticulina pela prata e a dificuldade de reconhecimento de fragmentos da leptospira, especialmente se poucos organismos estiverem presentes, limitam o sucesso no emprego dessa técnica histoquímica (Wild et al. 2002). Por outro lado, os resultados positivos com aglutininas anti-sorovariedade Hardjo e o histórico de vacinação há aproximadamente 10 meses do rebanho corroboram o diagnóstico, uma vez que, segundo Chiareli et al. (2012) as vacinas anti-leptospiras são imunógenos fracos, gerando resposta imune do tipo humoral, com baixos títulos e por um curto período de tempo. Para Grooms et al. (2002), bovinos infectados com a sorovariedade Hardjo frequentemente têm resposta fraca de aglutinação de anticorpos, com possibilidade de títulos baixos ou negativos na época do aborto; e bovinos infectados e eliminando leptospiras têm títulos baixos de anticorpos anti-Hardjo.

Os resultados demonstram que agentes virais e bacterianos são responsáveis por abortos em bovinos na região estudada e que as técnicas de histologia e imuno-histoquímica são ferramentas úteis para o diagnóstico, principalmente quando não há acesso a exames bacteriológicos ou as amostras se encontrarem muito contaminadas ou formolizadas, impossibilitando esses exames.

Agradecimentos.- Aos Professores Dr. Eduardo Furtado Flores (UFSM) e Dr. Renato de Lima Santos (UFMG), que gentilmente cederam alíquota dos anticorpos anti-Herpesvírus e anti-Brucella abortus, respectivamente, e a FAPEMIG, pela bolsa de mestrado e pelo apoio financeiro concedidos.

\section{REFERÊNCIAS}

Alves T.M., Stynen A.P.R., Miranda K.L. \& Lage A.P. 2011. Campilobacteriose genital bovina e tricomonose genital bovina: epidemiologia, diagnóstico e controle. Pesq. Vet. Bras. 31:336-344.

Antoniassi N.A.B., Juffo G.D., Santos A.S., Pescador C.A., Corbellini L.G. \& Driemeier D. 2013. Causas de aborto bovino diagnosticadas no Setor de Patologia Veterinária da UFRGS de 2003 a 2011. Pesq. Vet. Bras. 33:155160.

Barr B.C., Anderson M.L., Blanchard P.C., Daft B.M., Kinde H. \& Conrad P.A. 1990. Bovine fetal encephalitis and myocarditis associated with protozoal infections. Vet. Pathol. 27:354-361.

Carvalho Neta A.V., Mol J.P.S., Xavier M.N., Paixão T.A., Lage A.P. \& Santos R.L. 2010. Pathogenesis of bovine brucellosis. Vet. J. 184:146-55.

Chiareli D., Casete M.R.V., Moreira E.C., Leite R.C., Lobato F.C.F., Silva J.A., Teixeira J.F.B. \& Marcelino A.P. 2012. Controle da leptospirose em bovinos de leite com vacina autógena em Santo Antônio do Monte, Minas Gerais. Pesq. Vet. Bras. 32:633-639.

Corbellini L.G., Driemeier D., Cruz C.F.E., Gondim L.F.P. \& Wald V. 2002. Neosporosis as a cause of abortion in dairy cattle in Rio Grande do Sul, southern Brazil. Vet. Parasitol. 103:195-202.

Cortez A., Castro A.M.G., Heinemann M.B., Soares R.M., Leite R.C., Scarcelli E., Genovez M.E., Alfieri A.A. \& Richtzenhain L.J. 2006. Detecção de ácidos nucléicos de Brucella spp., Leptospira spp., herpesvírus bovino e vírus da diarréia viral bovina, em fetos bovinos abortados em animais mortos no perinatal. Arq. Bras. Med. Vet. Zootec. 58:1226-1228.

Crook T., Benavides J., Russell G., Gilray J., Maley M. \& Willoughby K. 2012. Bovine herpesvírus 1 abortion: current prevalence in the United Kingdom and evidence of hematogenous spread within the fetus in natural cases. J. Vet. Diagn. Invest. 24:662-670.

Enright F.M., Walker J.V., Jeffers G. \& Deyoe B.L. 1984. Cellular and humoral resposes of Brucella abortus-infected bovine fetuses. Am. J. Vet. Res. 45:424-430.

Flores E.F. \& Schuch L.F.D. 2007. Diarreia viral bovina, p. 81-93. In: Riet-Correa F., Schild A.L., Lemos R.A.A., Borges J.R.J. (Eds), Doenças de Ruminantes e Equídeos. $3^{a}$ ed. Pallotti, Santa Maria. 
Grooms D.L., Baker J.C. \& Ames T.R. 2002. Diseases caused by bovine vírus diarrhea vírus, p.707-714. In: Smith B.P. (Ed.), Large Animals Internal Medicine: diseases of horses, cattle, sheep and goats. $3^{\text {rd }}$ ed. Mosby, St Louis, MO.

Hong C.B., Donahue J.M., Giles Jr R.C., Poonacha K.B., Tuttle P.A. \& Cheville N.F. 1991. Brucella abortus-associated meningitis in aborted bovine fetuses. Vet. Pathol. 28:429-496.

Kirkbride C.A. 1992. Viral agents and associated lesions detected in a 10 -year study of bovine abortions and stillbirths. J. Vet. Diagn. Invest. 4:374-379.

Oldoni I., Weiblen R., Inkelmann M.A. \& Flores E.F. 2004. Production and characterization of monoclonal antibodies to a Brazilian bovine herpesvírus type 5. Braz. J. Med. Biol. Res. 37:213-222.

Orlando D.R., Costa R.C., Soares B.A., Oliveira N.S.C., Nascimento l.C., Peconick A.P., Raymundo D.L. \& Varaschin M.S. 2013. Abortos por Neospora caninum em bovinos do sul de Minas Gerais. Pesq. Vet. Bras. 33:13321338.

Rodger S.M., Murray J., Underwood C. \& Buxon D. 2007. Microscopical lesions and antigen distribution in bovine fetal tissues and placentae following experimental infection with bovine herpesvírus-1 during pregnancy. J. Comp. Pathol. 137:94-101.

Szeredi L. \& Haake D.A. 2006. Immunohistochemical identification and pathologic findings in natural cases of equine abortion caused by leptospiral infection. Vet. Pathol. 43:755-761.

Varaschin M.S. \& Wouters F. 2006. Patologia Especial das Principais Doenças Transmitíveis na Reprodução de Bovinos. UFLA, Lavras. 52p.

Wild C.J., Greenlee J.J., Bolin C.A., Barnett J.K., Haake D.A. \& Cheville N.E. 2002. An improved immunohistochemical diagnostic technique for canine leptospirosis using antileptospiral antibodies on renal tissue. J. Vet. Diagn. Invest. 14:20-24. 